\title{
CLIENT INFLUENCE ON VALUATION: PERCEPTUAL ANALYSIS OF THE DRIVING FACTORS
}

\author{
Abdul - Rasheed AMIDU ${ }^{1}$ and Bioye Tajudeen ALUKO ${ }^{2}$ \\ 1 Department of Estate Management, Obafemi Awolowo University, Ile-Ife, Nigeria \\ E-mail: amidrasheed@yahoo.co.uk \\ 2 Department of Estate Management, Obafemi Awolowo University, Ile-Ife, Nigeria \\ E-mail: btaluko@oauife.edu.ng
}

Received 14 June 2006; accepted 28 February 2007

\begin{abstract}
Recent behavioural real estate research effort on valuation bias judgement suggests that client influence is an important source of such bias. This paper, therefore, considers the theoretical potentials for client influence to bias valuations, and empirically analyse the factors impacting on the extent of influence client may exert on estate surveyors and valuers. To accomplish this aim, questionnaires were randomly administered to samples of estate surveyors and valuers in Lagos Metropolis. Using mean rating point, the survey ranked three factors; integrity of valuer or valuation firm, importance of the valuation outcome to the client and client size, as the most significant clients' influencing factors. The results of the Chi-square test did not, however, provide any statistical relationship between the size of firm, amount of experience and education of estate surveyors and valuers and their perception on the comparative importance of the identified clients' influencing factors.
\end{abstract}

KEYWORDS: Client influence; Property valuation; Empirical analysis; Driving factors; Estate surveyors and valuers

\section{INTRODUCTION}

In the light of the subjectivity nature of property valuations, an important issue that has engaged the attention of real estate researchers over the last decade is the disparity between property transaction prices and market values. To date, the consensus, except for the study of Lai and Wang (1998), is that valuations are generally not accurate estimates of market values. The evidence to that effect, according to Levy and Schuck (1998, 1999), falls in three areas. First anecdotal evidence clearly indicates that practitioners believe valuations are lagged estimates of market value (i.e. Webb, 1994). Second, empirical studies that analyze the relationship between transaction prices and contemporaneous valuations also conclude frequently that incongruence between these variables is evidence of error (see for example Zotzour, 1988a, 1988b; Diaz, 1997; Diaz and Wolverton, 1998). Third, empirical studies that investigate the statistical properties of time series of valuation based returns conclude that serial correlation is evidence of bias (e.g. Ibbotson and Siegel, 1984; Cole, 1988; Geltner, Graff and Young, 1994; Geltner and Geotzmann, 1998; Geltner, 1993, 1998; Young and Graff, 1995; Graff, Harrington and Young, 1997).

Valuers' error in price predictions arises from random variation in observed prices of

International Journal of Strategic Property Management

ISSN 1648-715X print / ISSN 1648-9179 online @ 2007 Vilnius Gediminas Technical University

http://www.ijspm.vgtu.lt 
comparable sales. For instance, any individual property at a particular point in time has, possibly, different prices due to different circumstances of sale, deferring buyer preferences, different buyer information sets or other factors which the valuer is unable to effectively account for (Aluko, Ajayi and Amidu, 2004). A number of factors, however, contribute to the existence of random error; including the generally poor quality and quantity of information available to valuers, the shortcoming in valuation methodologies and a disparity between the definitions of 'market value' and the figure that a valuer seeks to estimate. Valuations are believed not only to suffer from random error but also from measurement and misspecification errors, also known as "interpretative errors" (Aluko, 2000), in the price differences models, which in turn increases as more comparables are added (Aluko, 2000; Kummerrow and Galfary, 2002; French and Gabrielli, 2004).

Recently, the quest to explain the error in valuations has tended to centre on behavioural attitudes of the parties to the production of valuations. This, according to Diaz (2002) is premised on the simple argument that before valuation improvement can be engineered, valuation behaviour must be understood. Behavioural real estate research, however, was initially focused on understanding the actual valuer problem solving in terms of departure from normative models (Diaz, 1987, 1990; Diaz et al., 2002), bias in the process of selecting comparable sales (Gallimore and Wolverton, 1997), heuristic problem solving behaviour (Gallimore, 1994, 1996; Diaz, 1997) and anchoring behaviour (Harvard, 1999, 2001; Cypher and Hansz, 2003; Diaz, 1997; Diaz and Hansz, 1997, 2001; Hansz, 2004a; 2004b; Hansz and Diaz, 2001; Diaz and Wolverton, 1998). All these studies tend to establish the fact that an expert usually solves problems in a manner that is inconsistent from the way in which he/she learned to solve them as a novice, thus leading to valuation judgement bias.
More recent research effort, apparently looking beyond valuation issues per se, has uncovered evidence of influence (from client, market and valuers) as also a likely cause of biased estimates of market values (see for example, Gallimore, 1994, 1996; Worzala et al., 1998; Kinnard et al., 1997; Roberts and Roberts, 1991; Smolen and Hambleton, 1997; Rushmore, 1993; Wolverton and Gallimore, 1999; Gallimore and Wolverton, 2000; Levy and Schuck, 1998; 1999; Amidu, 2006; Amidu and Aluko, 2007). These studies set out a body of theory and empirical evidence, which suggests that relationship between clients and valuers, would influence the valuation formation process. Except for the study of Levy and Schuck (1999) and Amidu (2006) that has consider the entire issue of client influence holistically, others have concentrated either on ascertaining whether specific type of influence exists or on the reactions of valuers in turn. The study of Levy and Schuck (1999), however, only qualitatively identified factors potentially impacting on the type and amount of influence client may exert on a valuers and ultimately the reported value of a property. This study contributes to knowledge by providing an empirical analysis of the factors from the view point of professionals in valuation practice in Nigeria.

\section{DATA DESCRIPTION AND METHODOLOGY}

The theoretical expectation about the potential that clients have for influencing valuations as developed in Levy and Schuck (1999) forms the basis upon which an empirical analysis of clients' influencing factors was carried out. According to the authors, such potential depends on several factors that can be categorised under four main headings, as shown in Figure 1.

These factors determine the extent of influence that may be brought to bear on valuers and the valuation process. However, only the characteristics of individual valuer and valuation firms and the characteristics of the 


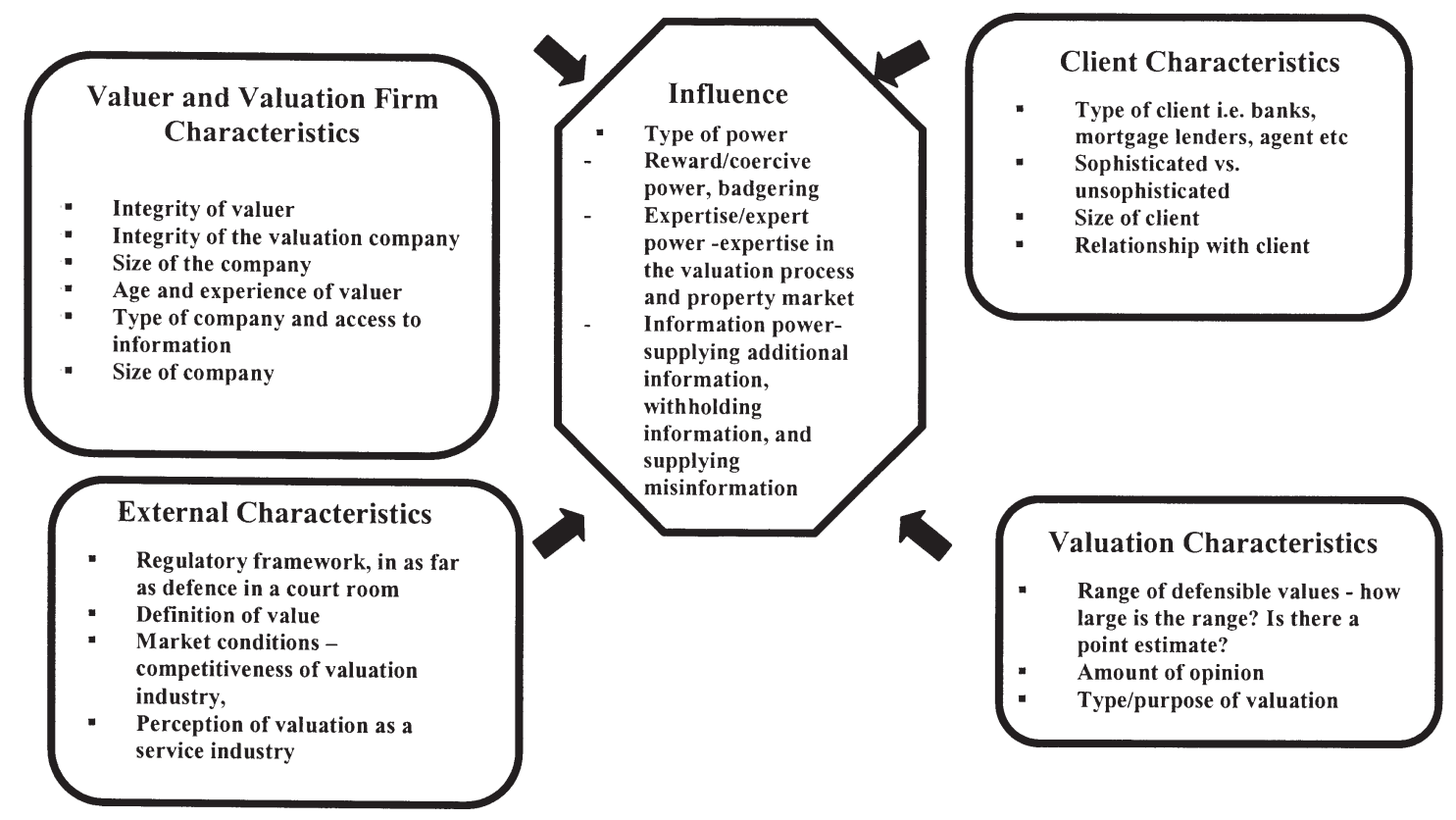

Figure 1. Expected Factors Affecting Client Influence as Reported by Valuers

Source: Levy and Schuck (1998), p. 21

clients were adopted for this study since the rest do not relate to client influence but rather to procedural influences that may not necessarily emanate from clients. Variables under these two factors include:

i. Integrity of the valuer and or ethical culture of the valuation firm.

ii. Earnings of the valuer/valuation firm from a client.

iii. Number of task undertaken for a client.

iv. Valuer's prior involvement with the subject property.

v. Size of a valuation firm.

vi. Valuer's involvement in other consultancy work for the client.

vii. Valuer's style of decision - making.

viii. Type of client (sophisticated and unsophisticated).

ix. Client size (big or small).

$\mathrm{x}$. Importance of the valuation outcome to the client.

xi. Client's financial condition.
The estate surveyors and valuers' perception of the significant of these factors as they affect possible client influence (by way of either encouraging client to put pressure or helping the valuer to resists such pressure) was measured on a 5 point likert format from 1 (strongly disagree) to 5 (strongly agree). The Estate Surveying and Valuation Firms or Estate Surveyors and Valuers, by virtue of the Estate Surveyors and Valuers Act No 24 of 1975 , are statutorily empowered to value proprietary interest in land for all purposes. According to the Institution directory (2003), approximately 52 percent (228) of firms practicing estate surveying and valuation in Nigeria have their headquarter offices located in Lagos Metropolis, the study area. Consequently, a random sample of 137 estate firms, representing $60 \%$ of firms in the study area and $31 \%$ of firms in Nigeria, were selected. Questionnaires were then personally administered to the Head of Valuation Department of the selected firms. The valid 88 responses to the measure used in 
the analysis shows a total response rate of $64 \%$, representing $39 \%$ for the study area and $20 \%$ in the whole country.

The study employed both descriptive and statistical methods of data analysis. These comprise frequency distribution, cross tabulation and chi square. The frequency distribution shows the basic distributional features of the data on the respondents' estate surveyors and their respective firms and also the data employed in the subsequent statistical analysis. The descriptive statistics like mean was used to rank the variables in addition to frequency and percentage distributions.

Finally, cross tabulation and chi square test was employed to determine whether the differences in the rating of the variables could be based on the size of firm, the amount of education and level of valuation experience of respondents.

\section{EMPIRICAL RESULTS}

\subsection{General information}

In order to establish the reliability of the data collected for this study; which is a meas- ure of the suitability of the target population, the study sought information on issues relating to the characteristics of the sampled firms and the responding estate surveyors and valuers. Respondents were, for instance, asked to indicate their firms' areas of professional practice. Their responses are as given in Table 1.

The table indicates that the entire responding estate surveying and valuation firm have more than one areas of professional practice. When the facets of professional practice are considered individually, $87.5 \%$ of the 88 firms sampled engage in property valuation, $92 \%$ in agency, $60.2 \%$ in property development, $88.6 \%$ in property management and $79.5 \%$ in general real estate services. These results attest to the fact that the sampled firms are very relevant to this research work.

Also for effective coverage, the sample of the 88 estate surveying and valuation firms were further stratified using the age of establishment as indicated in Table 2.

Table 2 shows that all the age groups are represented by the estate surveying and valuation firms. The sample of the firms is well spread representing 17\%, 21.6\%, 23.9\%, 4.5\% and $33.0 \%$ of the age groups ranging between

Table 1. Firms' area of professional practice

\begin{tabular}{lll}
\hline Professional practice & Yes $(\%)$ & No $(\%)$ \\
\hline Property valuation & $77(87.5)$ & $11(12.5)$ \\
Estate agency & $81(92.0)$ & $7(8.0)$ \\
Property development & $53(60.2)$ & $35(39.8)$ \\
Property management & $78(88.6)$ & $10(11.4)$ \\
General real estate services & $70(79.5)$ & $18(20.5)$ \\
\hline
\end{tabular}

Table 2. Year of establishment of firm

\begin{tabular}{llll}
\hline Year & Frequency & Percent & Cumulative percent \\
\hline Between 1 - 5 years & 15 & 17.0 & 17.0 \\
Between 6 - 10 years & 19 & 21.6 & 38.6 \\
Between 11 - 15 years & 21 & 23.9 & 62.5 \\
Between 16 - 20 years & 4 & 4.5 & 67.0 \\
Above 20 years & 29 & 33.0 & 100 \\
\hline Total & 88 & 100 & \\
\hline
\end{tabular}


$1-5,6-10,11-15,16-20$, and Above 20 years respectively. This clearly established the inclusion of both new and old generation firms of estate surveying and valuation. The respondents are therefore believed to be conversant with up to date developments in the field of property valuation. Consequently, the data should reflect the status of valuation practice in the study area.

In addition to the foregoing, the characteristics of the respondents' estate surveyors and valuers were equally examined with a view to establishing their suitability for the study. Table 3 presents the descriptive statistics to that effect.

A majority of the respondents had a Bachelor Degree (55.7\%) while 36.4\% had Higher National Diploma in Estate Management. With these results, a significance large majority $(92.1 \%)$ of the respondents possess top - level educational qualification in the theory and practices of property valuation. This, therefore, makes the data more revealing and dependable as far as the subject matter of this study is concerned.

Moreover, all the respondents' estate surveyors and valuers are members of the Nigerian Institution of Estate Surveyors and Valuers (NIESV, 2003) with different membership designations, 98.8\% for Associates and 1.2\% for Fellows. Table 3 also shows that about $53.4 \%$ of the respondents have $1-5$ years post qualification valuation experience while $30.7 \%$, $11.4 \%, 2.3 \%$ and $2.3 \%$ have $6-10,11-15$, $16-20$ and Above 20 years post qualification valuation experience. With this background, the next section examines the view of estate surveyors and valuers on the clients' influencing factors.

\subsection{Clients' influencing factors}

Estate surveyors and valuers in the study area were asked to identify the perceived significant and insignificant of the factors to client influence and, consequently, upon the extent of possible influence a client could exert on valuers and the valuation process. Table 4 indicates the responses.

It is evidenced from the table that more than $50 \%$ estate surveyors and valuers agreed with all the factors, except valuer's style of decision making (48.8\%), as potentially impacting on client influence. These findings are entirely a validation of earlier researches conducted in both auditing and valuation industries, which appeared to be similar, structure wise. For instance, it has been suggested in

Table 3. Characteristics of the respondents estate surveyors and valuers

\begin{tabular}{lll}
\hline Variable & Frequency & Percent \\
\hline Academic qualification & & \\
\hline Higher national diploma & 32 & 36.4 \\
Bachelor degree & 49 & 55.7 \\
Master degree & 7 & 8.0 \\
\hline Professional qualification & & \\
\hline ANIVS & 87 & 98.8 \\
FNIVS & 1 & 1.1 \\
\hline Year of valuation experience & & \\
\hline Between 1 - 5 years & 47 & 33.4 \\
Between 6 - 10 years & 27 & 30.7 \\
Between 11 - 15 years & 10 & 11.4 \\
Between 16 - 20 years & 2 & 2.3 \\
Above 20 years & 2 & 2.3 \\
\hline
\end{tabular}




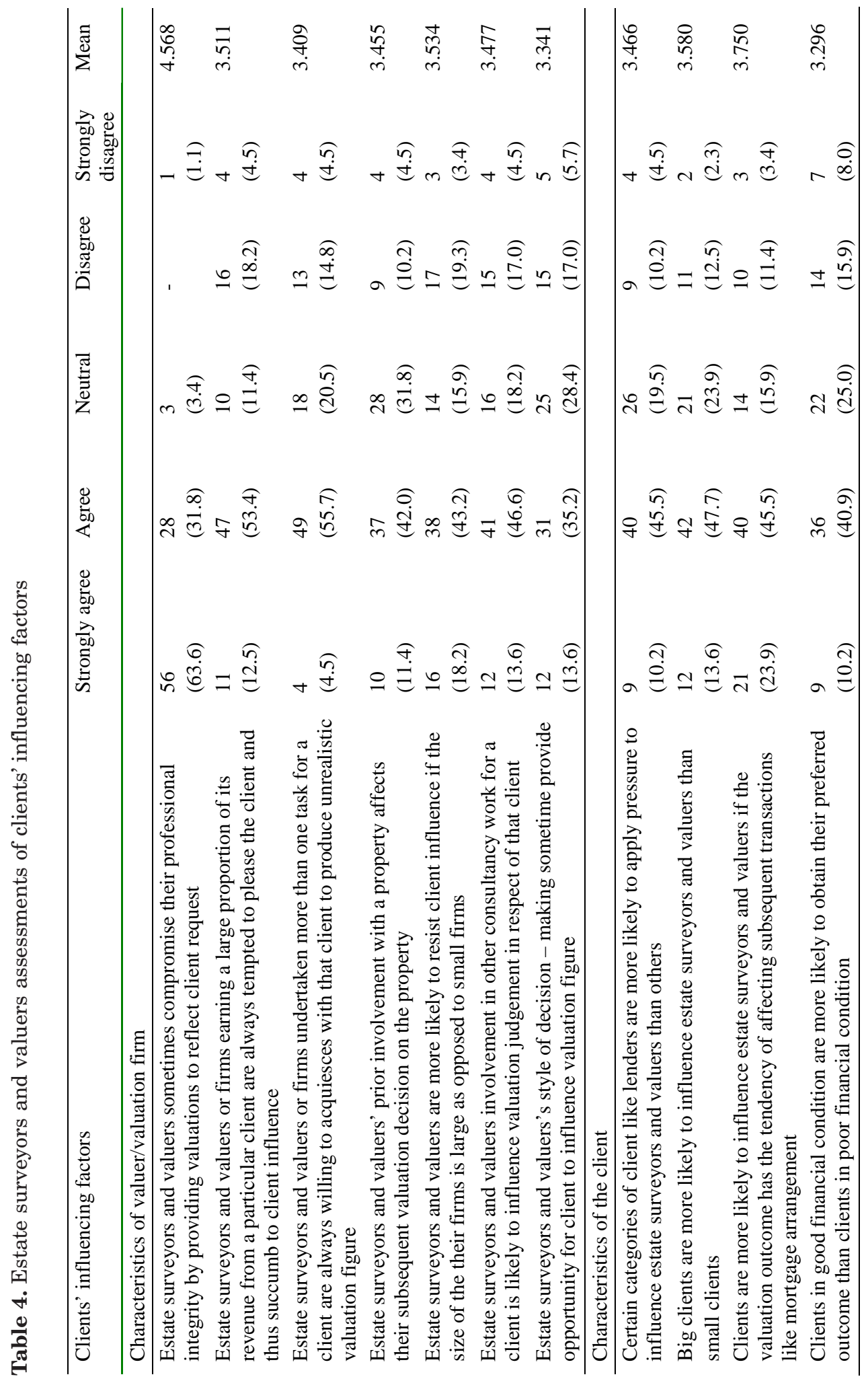


the auditing literature (see Poneman, 1992 for example) that ethical culture may exists in a company and that would be influenced by employees in positions to promote staff who tend to favour individuals possessing "ethical reasoning" that is closed to their own capacity. Consequently, and, in the valuation parlance, the scenario tend to suggests that different estate surveying and valuation firms as well as individual estate surveyors and valuers may possess differing levels of integrity and ethical behaviour that could enable the firm or the valuer to either resist client possible influence or cave in. Subjecting this variable to the perceptual view of estate surveyors and valuers, an overwhelming number of respondents (95.4\%) agreed that some estate surveyors and valuers actually do compromise their integrity and commitment as objective estimators of value.

In examining the issue of the earnings of valuers or valuation firms from clients, the perception of estate surveyors and valuers appeared to correspond to that of appraisers in the US as reported in the study of Smolen and Hambleton (1997). With mean response of 3.511 , majority $(65.9 \%)$ of estate surveyors and valuers supports the view that a firm earning a large percentage of its revenue from a single client may be tempted to "please" that client when a request for unrealistic valuation figure is made by the client. This tendency may, however, be greater in Nigeria because of the competitive nature of the industry vis a viz the quest by practitioners to retain their clients and thus sustain their business.

Also, in a situation where an estate surveyor and valuer or the firm undertakes more than one task for a client, the perception of the responding estate surveyors and valuers, with $60.2 \%$ in agreement, is that such a professional or the firm is more likely to be unable to resist possible threats from such a client to produce unrealistic valuation. This view has been established in the auditing industry as well. The study of Lindsay (1989), for instance, identified the situation where an audit firm provides management consultancy to its client as one in which the auditor is more likely to acquiesce with the client.

Similarly, it has also been confirmed in the auditing literature (see Church and Schneider's, 1993) that the involvement of independent auditors in the design of an audit programme affects their subsequent audit work related to that audit area. This scenario, according to Levy and Schuck (1999), may be well applied to the valuation industry in cases where a valuer may have previously recommended a client purchase a property for a particular price and subsequently becoming committed to the recommendation to please their client. About $53.4 \%$ of the responding estate surveyors and valuers agreed with this view, thus confirming the case of possible biasness towards a particular client even when an express request has not been made.

With respect to the size of the valuation firm, $61.4 \%$ of respondents' estate surveyors and valuers support the view that estate surveyors and valuers are more likely to resist possible client influence if they are engaged by big and well established firms. This factor, Smolen and Hambleton (1997) have noted, could even make valuers more vulnerable to client influence where the valuation industry is characterised by many small firms. And, as evidenced from the year of establishment of sampled firms (more than half, $55.6 \%$, established between $1-10$ years) the situation could even be worse in our local context. More so that the average monthly salary paid by estate surveying and valuation firms to registered estate surveyors and valuers is below N50, 000 (US\$400).

In addition to the foregoing characteristics of individual valuer and valuation practice, certain client characteristics identified to have effects on client influence were also measured from the view point of estate surveyors and valuers. For instance, about $55.7 \%$ of estate surveyors and valuers sampled agreed to the statement "certain categories of client are more likely to apply pressure to influence valuers 
to report unrealistic valuation". Still on this factor, Amidu (2006) and Amidu and Aluko (2007) found that private individuals such as borrowers were the primary source of client influence in Nigeria followed by lending institutions. This, however, contradicts the position in the US where Smolen and Hambleton (1997) identified mortgage bankers as being the primary sources of client influence followed by commercial banks. Kinnard et al., (1997) also found that valuers experienced significant pressure from certain types of client especially mortgage brokers and bankers.

Responding estate surveyors and valuers also agreed $(61.3 \%)$ to the view that big clients are more likely to influence valuation than small clients. This complements the study of Kinnard et al., (1997) where a direct relationship between client size and the likelihood of valuers revising their reported values in the UK was found to exist. Such relationship could not, however, be established in the studies of Amidu and Aluko (2007) of the Nigerian estate surveyors and valuers and Worzala et al., (1998) of US appraisers.

On the importance of a valuation to client, real estate literature seem to suggest that the more urgently a required valuation outcome is needed by a client, the more likely the client will exert influence on the valuer to come up with a particular reported value. This, according to Rutledge (1994) and Kinnard et al., (1997), may manifest itself in situations for example, where an investment manger's compensation is directly related to valuation outcome. Other situations where the outcome of a valuation is important for a client, and which the responding estate surveyors and valuers were asked to express their view on is where a deal or lean is dependent on a particular valuation figure. About $69.4 \%$ of respondents agreed that lenders in such a situation are more likely to influence estate surveyors and valuers to report a valuation figure that would justify the loan amount required.
The foregoing, therefore, confirmed all the factors as significant client influencing factors that could affect the extent of influence a client is able to put on estate surveyors and valuers' reported value in property valuation. However, in order to develop the comparative importance of the variables, the mean rating point (as contained also in table 4) was estimated for each of the variables. The technique demonstrates that from the perception of estate surveyors and valuers in the study area, the three most significant clients' influencing factors with the highest mean rating point are integrity of valuer or valuation firm (4.568), importance of the valuation outcome to the client (3.750) and client size (3.580). This rating was not unexpected as they appear to be a reflection of the major challenges facing the practice of estate surveying and valuation profession in Nigeria. For instance, the study of Amidu (2006) has provided documented evidence in support of the allegations that client influence exist in Nigerian valuation industry, just as it has been established in the US (Kinnard et al., 1997; Smolen and Hambleton, 1997), UK (Baum et al., 2000) and New Zealand (Levy and Schuck, 1999). Given this, it can be logically concluded that most practicing estate surveyors and valuers are not complying with established code of conduct regulating their profession and, consequently, not maintaining high level of integrity and commitment required of practitioners. Although, the Nigerian Institution of Estate Surveyors and Valuers (NIESV, 2003) through its Professional Practice Committee, has the power to take appropriate disciplinary action against erring members, majority of practitioners are still not truly committed to the course of the profession, through compliance with the institution 1985 Guidance Notes on Property Valuation. This was confirmed by the President (Otunba Tade Ismail) of the Institution from 1997 - 1998 in his welfare message:

"- - - I have been exposed to the complexity of running the affairs of fully qualified professional people, probationers and students. Off 
all the categories, the fully qualified people have been by far, the most difficult to manage. The issues have invariable been those of materialism and unbridled ambition - - "

In order to test whether there is a relationship between the size of firm, the amount of experience and education an estate surveyor and valuer has and their perception on the clients' influencing factors, the estate surveyors and valuers' questionnaire responses were further analysed using Chi-square tests. The results of these tests are set out at Appendix.

There appeared to be no statistical association between the size of firm, amount of experience and education of estate surveyors and valuers and their opinion on the potentials of the three variables: integrity of valuer or valuation firm, importance of the valuation outcome to the client and client size to affect client influence. This does not entirely rule out a relationship as it may be that, in responding to the question on the variable, estate surveyors and valuers have in mind a minority of cases. Nevertheless, the results suggest that estate surveyors and valuers would need to be re orientated towards guiding against client influence.

\section{CONCLUSION}

This paper empirically examines the factors potentially impacting on the extent of influence clients may possibly exert on estate surveyors and valuers and valuation outcome. Three factors, integrity of valuer or valuation firm, importance of the valuation outcome to the client and client size, were ranked; through mean rating point, as the three most significant clients' influencing factors from the view point of responding estate surveyors and valuers. The rating of these factors appeared to be a reflection of the problem of non - compliance of estate surveyors and valuers with the professional code of conduct, weaknesses in the current mortgage valuation practice in the country and the highly competitiveness nature of the valuation industry. These problems, if not urgently addressed could further affect the already damaged professional credibility of estate surveyors and valuers in the country. Consequently, the regulatory bodies would need to set up a mechanism to constantly monitor the activities of estate surveyors and valuers with a view to ensuring strict compliance with the institution code of conduct.

\section{REFERENCE}

Aluko, B. T. (2000) A Study of the Appropriateness of Mortgage Valuation for Institutional Lending in Nigeria, Unpublished PhD Thesis, Obafemi Awolowo University, Ile-Ife, Nigeria.

Aluko, B. T., Ajayi, C. A. and Amidu, A. (2004) The Estate Surveyors and Valuers and the Magic Number: A Point Estimate or a Range of Value? International Journal of Strategic Property Management, 8(3), p. 149-162.

Amidu, A. (2006) A Study of Client Influence on Residential Property Valuations in Lagos Metropolis, Unpublished M.Sc.Thesis, Obafemi Awolowo University, Ile-Ife, Nigeria.

Amidu, A. and Aluko, B. T. (2007) Client Influence in Residential Property Valuations: An Empirical Study. Property Management, Forthcoming.

Church, B. K. and Schneider, A. (1993) The Effect of Prior Involvement in Audit Programme Design. Accounting and Finance, 33(2), p. 61-78.

Cole, R. (1988) A New Look at Commercial Real Estate Returns, PhD Dissertation, University of North Carolina at Chapel Hill, Ann Arbor, Michigan: University Microfilms International.

Cypher, M. and Hansz, J. A. (2003) Does Assessed Value Influence Valuation Judgment? Journal of Property Research, 20(4), p. 1-14.

Diaz, J. (1987) Process Tracing Investigation into Problem Solving within Residential Real Estate Appraisal, Unpublished Dissertation, Georgia State University, U.S.

Diaz, J. (1990) How Appraisers do their Work: A Test of the Appraisal Process and the Development of a Descriptive Model. Journal of Real Estate Research, 5(1), p. 1-16.

Diaz, J. (1997) An Investigation into the Impact of Previous Expert Estimates on Appraisal Judgement. Journal of Real Estate Research, 13(1), p. 57-66. 
Diaz, J. (2002) Behavioural Research in Appraisal and some Perspectives on Implications for Practice, RICS Foundation Research Review Series, 2002, August.

Diaz, J., Gallimore, P. and Levy D. (2002) Residential Valuation Behaviour in the United State, the United Kingdom and New Zealand. Journal of Property Research, 19(4), p. 313-326.

Diaz, J. and Hansz, J. A. (1997) How Valuers Use the Value Opinion of Others. Journal of Property Valuation and Investment, 15(3), p. 256-260.

Diaz, J. and Hansz, J. A. (2001) The Use of Reference Points in Valuation Judgment. Journal of Property Research, 18(2), p. 141-148.

Diaz, J. and Wolverton, M. (1998) A Longitudinal Examination of the Appraisal Smoothing Hypothesis. Real Estate Economics, 26(2), p. 349358.

French, N. and Gabrielli, L. (2004) The Uncertainty of Valuation. Journal of Property Investment and Finance, 22(6), p. 484-500.

Gallimore, P. (1994) Aspects of Information Processing in Valuation Judgement and Choice. Journal of Property Research, 11(2), p. 97-110.

Gallimore, P. (1996) Confirmation bias in the valuation process: a test for corroborating evidence. Journal of Property Research, 13(4), p. 261-273.

Gallimore, P. and Wolverton, M. L. (1997) Priceknowledge-induced bias: a cross-cultural comparison. Journal of Property Valuation and Investment, 15(3), p. 261-273.

Gallimore, P. and Wolverton, M. L. (2000) The Objective in Valuation: A Study of the Influence of Client feedback. Journal of Property Research, 17(1), p. 47-58.

Geltner, D. M. (1998) How Accurate is the NCREIF Index as a Benchmark and who Cares? Real Estate Finance, 14(4), p. 25-37.

Geltner, D. M. (1993) Temporal Aggregation in Real Estate Returns Indices. Real Estate Economics, 21(2), p. 141-166.

Geltner, D. M. and Geotzmann, W. N. (1998) Two Decades of Commercial Property Returns: A NCREIF Index Using Independent Appraisals, Working Paper, Cincinnati, O.H: University of Cincinnati.

Geltner, D. M., Graff, R. A. and Young, M. S. (1994) Random Disaggregate Appraisal Error in Commercial Property: Evidence from the RussellNCREIF Database. Journal of Real Estate Research, 9(4), p. 403-419.
Graff, R. A., Harrington, A. and Young, M. S. (1997) The Shape of Australia Real Estate returns Distributions and Comparison to the United States. Journal of Real Estate Research, 14(3), p. 291-308.

Hansz, J. A. (2004a) The Use of a Pending Mortgage Reference Point in Valuation Judgement. Journal of Property Investment and Finance, 22(3), p. 259-268.

Hansz, J. A. (2004b) Prior Transaction Price Induced Smoothing: Testing and Calibrating the Quan - Quigley Model at the Disaggregate Level. Journal of Property Research, 21(4), p. 321-336.

Hansz, J. A. and Diaz, J. (2001) Valuation Bias in Commercial Appraisal: A Transaction Price Feedback Experiment. Real Estate Economics, 29(4), p. 553-565.

Harvard, T. M. (1999) Do Valuers Have a Greater tendency to Adjust a Previous Valuation Upwards or Downwards? Journal of Property Investment and Finance, 17(4), p. 365-373.

Havard, T. M. (2001) An Experimental Evaluation of the Effect of Data Presentation on Heuristics Bias in Commercial Valuation. Journal of Property Research, 18(1), p. 51-68.

Ibbotson, R. G. and Siegel, L. B. (1984) Real Estate Returns: A comparison with other Investments. Real Estate Economics, 12(3), p. 219-242.

Kinnard, W. N., Lenk, M. M. and Worzala, E. M. (1997) Client Pressure on Commercial Appraisal Industry: How Prevalent is it? Journal of Property Valuation and Investment, 15(3), p. 233-244.

Lai, T-Y. and Wang, K. (1998) Appraisal Smoothing: The Other Side of the Story. Real Estate Economics, 26(3), p. 511-535.

Levy, D. and Shuck, E. (1998) Client Influence on Reported Values, Cutting Edge Conference, RICS, London.

Levy, D. and Shuck, E. (1999) The Influence of Clients on Valuations. Journal of Property Investment and Finance, 22(3), p. 259-268.

Lindsay, D. (1989) Financial Statement Users: Perceptions of factors affecting the Ability of Auditors to Resist Client Pressure in a Conflict Situation. Accounting and Finance, 29(2), p. 1-18.

NIESV (2003) Directory of Estate Surveyors and Valuers, Nigerian Institution of Estate Surveyors and Valuers, Lagos.

Roberts, J. R. and Roberts, E. (1991) The Myth about Appraisal. The Appraisal Journal, LIX(2), April, p. 212-220. 
Rushmore, S. (1993) Ethics in Hotel Appraising. The Appraisal Journal, LXI (3), July p. 357-363.

Smolen, G. E. and Hambleton, D. C. (1997) Is the Real Estate Appraiser's Role too Much to Expect? The Appraisal Journal, LXV (1), January, p. 9-17.

Webb, R. B. (1994) On the Reliability of Commercial Appraisals: An Analysis of Properties Sold From the Russell-NCREIF Index (1978-1992). Real Estate Finance, 11(1), p. 62-65.

Wolverton, M. L. and Gallimore, P. (1999) Client Feedback and the Role of the Appraiser. Journal of Real Estate Research, 18(7), p. 415-432.

Worzala, E. M., Lenk, M. M. and Kinnard, W. N.
(1998) How Client Pressure Affects the Appraisal of residential Property. The Appraisal Journal, 66(4), October, p. 416-427.

Young, M. S. and Graff, R. A. (1995) Real Estate is Not Normal: A Fresh Look at Real Estate returns Distributions. Journal of Real Estate Finance and Economics, 10(3), p. 225-259.

Zotzour, M. G. (1988a) The Impact of Professional Designation on Appraisal Variation in Corporate Relocation Appraisals. The Appraisal Journal, 56(4), p. 522-530.

Zotzour, M. G. (1988b) Quantifying Estimation Bias in Residential Appraisal. Journal of Real Estate Research, 3(3), p. 1-11.

\section{SANTRAUKA}

\section{KLIENTŲ İTAKA VERTINIMUI: PAGRINDINIŲ VEIKSNIŲ SUVOKIMO ANALIZE்}

\section{Abdul - Rasheed AMIDU, Bioye Tajudeen ALUKO}

Neseniai atlikti nekilnojamojo turto vertinimo šališkumo elgsenos tyrimai rodo, kad kliento ịtaka - svarbus tokio šališkumo šaltinis. Todèl šiame darbe svarstomas klientų įtakos vertinimo šališkumui teorinis potencialas ir empiriškai analizuojami veiksniai, lemiantys kliento įtakos nekilnojamojo turto vertintojams mastą. Rengiant ši darbą, buvo apklausti respondentai - atsitiktine tvarka parinkti nekilnojamojo turto vertintojai iš Lagoso miesto. Apskaičiuojant vidurkị, apklausos metu balais ịvertinti trys veiksniai yra svarbiausi, kuriems klientas gali daryti ịtaką - tai vertintojo arba vertinimo firmos sąžiningumas, vertinimo rezultatų svarba klientui ir kliento dydis. Tačiau chi kvadrato testo rezultatai neparode jokio statistinio ryšio tarp įmonès dydžio, turto vertintojų patirties bei išsilavinimo ir to, kaip jie supranta nustatytụų klientų ịtakos veiksnių lyginamąją svarbą. 


\section{APPENDIX}

\section{Cross tabulations and Chi Square test results}

\begin{tabular}{|c|c|c|c|c|c|c|}
\hline \multirow[b]{2}{*}{ Year of firm establishment } & \multicolumn{6}{|c|}{$\begin{array}{l}\text { Estate surveyors and valuers sometimes compromise their professional integrity by providing } \\
\text { valuations to reflect client request }\end{array}$} \\
\hline & Strongly agree & Agree & Neutral & Disagree & Strongly disagree & Total \\
\hline Between $1-5$ years & 10 & 5 & - & - & - & 15 \\
\hline Between $6-10$ years & 8 & 9 & 1 & - & 1 & 19 \\
\hline Between $11-15$ years & 17 & 4 & - & - & - & 21 \\
\hline Between $16-20$ years & 3 & 1 & - & - & - & 4 \\
\hline Above 20 years & 18 & 9 & 2 & - & - & 29 \\
\hline Total & 56 & 28 & 3 & - & 1 & 88 \\
\hline \multirow[t]{2}{*}{ Chi square test $\mathrm{p}$ value } & & & & & & 0.50 \\
\hline & \multicolumn{6}{|c|}{$\begin{array}{l}\text { Estate surveyors and valuers sometimes compromise their professional integrity by providing } \\
\text { valuations to reflect client request }\end{array}$} \\
\hline Year of valuation experience & Strongly agree & Agree & Neutral & Disagree & Strongly disagree & Total \\
\hline Between $1-5$ years & 30 & 15 & 2 & - & - & 47 \\
\hline Between $6-10$ years & 16 & 10 & - & - & 1 & 27 \\
\hline Between $11-15$ years & 8 & 2 & - & - & - & 10 \\
\hline Between $16-20$ years & 1 & 1 & - & - & - & 2 \\
\hline Above 20 years & 1 & - & 1 & - & - & 2 \\
\hline Total & 56 & 28 & 3 & & 1 & 88 \\
\hline \multirow[t]{2}{*}{ Chi square test $\mathrm{p}$ value } & & & & & & 0.10 \\
\hline & \multicolumn{6}{|c|}{$\begin{array}{l}\text { Estate surveyors and valuers sometimes compromise their professional integrity by providing } \\
\text { valuations to reflect client request }\end{array}$} \\
\hline Amount of education & Strongly agree & Agree & Neutral & Disagree & Strongly disagree & Total \\
\hline Higher national diploma & 21 & 9 & 2 & - & - & 32 \\
\hline Bachelor degree & 31 & 16 & 1 & - & 1 & 49 \\
\hline Master degree & 4 & 3 & - & - & - & 7 \\
\hline Total & 56 & 28 & 3 & - & 1 & 88 \\
\hline \multirow[t]{2}{*}{ Chi square test $\mathrm{p}$ value } & & & & & & 0.86 \\
\hline & \multicolumn{6}{|c|}{$\begin{array}{l}\text { Clients are more likely to influence estate surveyors and valuers if the valuation outcome has the } \\
\text { tendency of affecting subsequent transactions like mortgage arrangement }\end{array}$} \\
\hline Year of firm establishment & Strongly agree & Agree & Neutral & Disagree & Strongly disagree & Total \\
\hline Between $1-5$ years & 5 & 3 & 3 & 4 & - & 15 \\
\hline Between $6-10$ years & 3 & 9 & 3 & 2 & 2 & 19 \\
\hline Between $11-15$ years & 6 & 8 & 2 & 4 & 1 & 21 \\
\hline Between $16-20$ years & - & 3 & 1 & - & - & 4 \\
\hline Above 20 years & 7 & 17 & 5 & - & - & 29 \\
\hline Total & 21 & 40 & 14 & 10 & 3 & 88 \\
\hline \multirow[t]{2}{*}{ Chi square test $\mathrm{p}$ value } & & & & & & 0.22 \\
\hline & \multicolumn{6}{|c|}{$\begin{array}{l}\text { Clients are more likely to influence estate surveyors and valuers if the valuation outcome has the } \\
\text { tendency of affecting subsequent transactions like mortgage arrangement }\end{array}$} \\
\hline Year of valuation experience & Strongly agree & Agree & Neutral & Disagree & Strongly disagree & Total \\
\hline Between $1-5$ years & 12 & 23 & 5 & 7 & - & 47 \\
\hline Between $6-10$ years & 7 & 11 & 5 & 2 & 2 & 27 \\
\hline Between $11-15$ years & 2 & 4 & 2 & 1 & 1 & 10 \\
\hline Between $16-20$ years & - & 2 & - & - & - & 2 \\
\hline Above 20 years & - & - & 2 & - & - & 2 \\
\hline Total & 21 & 40 & 14 & 10 & 3 & 88 \\
\hline \multirow[t]{2}{*}{ Chi square test $\mathrm{p}$ value } & & & & & & 0.24 \\
\hline & \multicolumn{6}{|c|}{$\begin{array}{l}\text { Clients are more likely to influence estate surveyors and valuers if the valuation outcome has the } \\
\text { tendency of affecting subsequent transactions like mortgage arrangement }\end{array}$} \\
\hline Amount of Education & Strongly agree & Agree & Neutral & Disagree & Strongly disagree & Total \\
\hline Higher national diploma & 8 & 16 & 5 & 2 & 1 & 32 \\
\hline Bachelor degree & 13 & 20 & 7 & 7 & 2 & 49 \\
\hline Master degree & - & 4 & 2 & 1 & - & 7 \\
\hline Total & 21 & 40 & 14 & 10 & 3 & 88 \\
\hline Chi square test $p$ value & & & & & & 0.79 \\
\hline
\end{tabular}


(continued)

\begin{tabular}{|c|c|c|c|c|c|c|}
\hline \multirow[b]{2}{*}{ Year of firm establishment } & \multicolumn{6}{|c|}{$\begin{array}{l}\text { Big clients are more likely to influence estate surveyors and valuers than } \\
\text { small clients }\end{array}$} \\
\hline & Strongly agree & Agree & Neutral & Disagree & Strongly disagree & Total \\
\hline Between $1-5$ years & 1 & 7 & 4 & 3 & - & 15 \\
\hline Between $6-10$ years & - & 6 & 9 & 2 & 2 & 19 \\
\hline Between $11-15$ years & 4 & 10 & 4 & 3 & - & 21 \\
\hline Between $16-20$ years & - & 3 & 1 & - & - & 4 \\
\hline Above 20 years & 7 & 16 & 3 & 3 & - & 29 \\
\hline Total & 12 & 42 & 21 & 11 & 2 & 88 \\
\hline \multirow[t]{2}{*}{ Chi square test $\mathrm{p}$ value } & & & & & & 0.09 \\
\hline & \multicolumn{6}{|c|}{$\begin{array}{l}\text { Big clients are more likely to influence estate surveyors and valuers than } \\
\text { small clients }\end{array}$} \\
\hline Year of valuation experience & Strongly agree & Agree & Neutral & Disagree & Strongly disagree & Total \\
\hline Between $1-5$ years & 6 & 22 & 11 & 8 & - & 47 \\
\hline Between $6-10$ years & 5 & 14 & 5 & 2 & 1 & 27 \\
\hline Between $11-15$ years & - & 5 & 3 & 1 & 1 & 10 \\
\hline Between $16-20$ years & 1 & 1 & - & - & - & 2 \\
\hline Above 20 years & - & - & 2 & - & - & 2 \\
\hline Total & 12 & 42 & 21 & 11 & 2 & 88 \\
\hline \multirow[t]{2}{*}{ Chi square test $\mathrm{p}$ value } & & & & & & 0.39 \\
\hline & \multicolumn{6}{|c|}{$\begin{array}{l}\text { Big clients are more likely to influence estate surveyors and valuers than } \\
\text { small clients }\end{array}$} \\
\hline Amount of education & Strongly agree & Agree & Neutral & Disagree & Strongly disagree & Total \\
\hline Higher national diploma & 3 & 17 & 8 & 3 & 1 & 32 \\
\hline Bachelor degree & 8 & 20 & 12 & 8 & 1 & 49 \\
\hline Master degree & 1 & 5 & 1 & - & - & 7 \\
\hline Total & 12 & 42 & 21 & 11 & 2 & 88 \\
\hline Chi square test $\mathrm{p}$ value & & & & & & 0.81 \\
\hline
\end{tabular}

